\title{
スポーツ競技団体の役員として薬剤師に期待するもの
}

\author{
坂本陽一
}

\section{What the Japan Cycling Federation Hopes to Accomplish in Cooperation with Pharmacists in Doping and Implementing Effective Anti-Doping Controls}

\author{
Yoichi SAKAMOTO \\ Japan Cycling Federation, Nihon Jitensha Kaikan 3 goukan, \\ 1-9-3 Akasaka, Minato-ku, Tokyo 107-0052, Japan
}

(Received August 31, 2011)

\begin{abstract}
Today the number of international cycling races has increased markedly compared with the past, and inevitably there are many riders traveling all over the world to participate in these events. It is inevitable that riders often become exposed to many more drugs at the cycling venues or through the internet where a wide selection of drugs is available. According to Union Cycliste Internationale (UCI) regulations, riders must report to a Doping Control Officer (DCO) any medications taken in the $72 \mathrm{~h}$ preceding a race. High level international teams are very familiar with these regulations and submit these reports with little problem. Lower level teams with less expertise, however, tend to have much more trouble submitting these reports. The close cooperation with pharmacists is believed to promoting the healthy development of the sport. To improve anti-doping controls, I strongly believe that good communication among staff during the events to exchange information smoothly and also good education through regular seminars and symposia for the staff involved are definitely needed. In other words, we have to develop human resources to build up a firm foundation to constantly generate future leaders.
\end{abstract}

Key words — - stage race; Union Cycliste Internationale (UCI) regulation; prohibited medication

\section{薬剤師との係わり}

競技団体は，その種目を総括する国際競技連盟 (IF: International Federation) と国内競技連盟 (NF: National Federation）からなります。自転車競技で 申しますと, IF が UCI（国際自転車競技連合： Union Cycliste Internationale）であり， NF が JCF （日本自転車競技連盟：Japan Cycling Federation） に該当します。

WADA (World Anti-Doping Agency : 世界アン チドーピング機構）やJADA（Japan Anti-Doping Agency：日本アンチドーピング機構）が設立され る以前は，各競技連盟が独自のアンチドーピング規 則を持っており，1999 年 3 月，UCI アンチドーピ ング規則の中にある禁止薬物の効能（主なドーピン

日本自転車競技連盟（干107-0052 東京都港区赤坂 1-9

-3 日本自転車会館 3 号館 3 階)

e-mail: y-sakamoto@staff.tohoku-gakuin.ac.jp

本総説は, 日本薬学会第 131 年会シンポジウム S36 で

発表したものを中心に記述したものである.
グ物質とその副作用 23 ページ）を自国の言語に翻 訳し，加盟団体や選手に徹底するように指示があり ました。そのことを実践した証拠に翻訳物を UCI に送るよう確認を求められました。対応期限が 7 日 間くらいしかなく狼狽しましたが，協力してくれる 薬剂師がいらしたおかげで NF の立場が保てまし た.この件が, 本連盟と薬剤師との係わりの最初の 内容になります。

\section{自転車競技の特性}

競技種目を挙げてみますと，トラック，ロード， マウンテンバイク，シクロクロス， BMX，インド アサイクリング，パラサイクリングなどが挙げら れ，当然のことですが，これらすべての種目がドー ピング検査の対象となります。その中にあって，特 にロード競技に，ドーピングの歴史を垣間見ること ができます。なぜロード競技なのか.ロード競技の 中のステージレースを例に取って説明してみます. ステージレースの特徴は, 大会日数, 走行距離が長 いことです。このレースで最も有名なツールドフラ 
ンスの今年度大会を例にとってみますと，一日の走 行距離が 100 キロ以上で，長く走る日は 250 キロ以 上走行する日もあります。大会日数も 3 週間もあ り，大会期間中の総走行距離は 3430 キロにもなり ます。これらの条件の中で選手，監督は，試合の疲 労回復，勝利へのプレッシャーと闘いながらの連日 になります。これらから逃れるために薬物使用に走 るのではないかと想像することができます。

\section{UCI の動き}

UCI は他の IF と比較して，アンチドーピングに 関しての規則や機関の組織内への立ち上げが早かっ た IF ではなかったと考えられます。2001 年にUCI が発刊した冊子“40 years of fighting against doping”によると，1964 年に世界のスポーツ団体とし て初めて，Medical Commission を立ち上げ，1969 年には Medical Control Regulation を作りました.

この背景には 1967 年に行われたツールドフラン スにおいて，トム・シンプソンという英国選手の死 亡事故があり，その事故の原因が禁止薬物使用によ るものであったことから，選手保護の立場とドーピ ング問題が伝統あるこの大会へ及ぼす影響を考慮 し，早急に立ち上げたものと考えられます。

検査に係わるスタッフの名称は現在，WADA，

IF，JADA 共通で DCO（ドーピングコントロール オフィサー）という名称になりましたが，Medical Commission 立ち上げ当時は, Medical inspector と 呼ばれており，1997に Antidoping inspector に呼び 名が変更になり，しばらくこの呼ばれ方が続きまし た。ここ数年前から現在の呼び名, DCO (Doping Control Officer）に変更になったところです．

日本国内のアンチドーピング活動の歴史と現状

日本国内のアンチドーピング活動について，ツー ルド北海道国際大会を例にとって記してみます。こ の大会は, 1987 年に始まり, 1997 年から国際大会 に移行し現在に至っています。ドーピング検査につ いては，国際大会に移行した 1997 年から検査を実 施するにあたり，参加チームの薬物使用の実態把握 を目的に使用薬物のリス卜提出を義務付けてみまし た。 UCI 規則では検査官の判断により，スタート 72 時間前までに使用した薬物のリストを提出させ ることができることになっています。このことによ り判明したことがいくつかあります。まず，薬物に 対する認識に関して，強豪チームほど，チーム所属
選手が取得している薬物の詳細について把握がされ ているということです。弱小チームはこれとは逆に 十分な把握がされていない実態が把握できました. さらにこの弱小チームの薬物に対する認識を分析し てみると，大会に出場する選手というよりは，一般 の方とあまり変わらない薬の使用状況があることが わかりました，具体的にいうと，風邪薬を始め，禁 止薬物を含有しているだろうと思われる薬を無意識 に近い状態で使用していたことを知ることができま した，とりわけ，学生チームにおける薬物の申請書 には驚く内容が多くありました。この状況を踏ま え，講習会などで認識を改めるよう指導を行うよう になり，現在を迎えています。

\section{薬剤師への期待}

アンチドーピング検査スタッフの中に薬に精通し ている薬剤師さんがいるというだけで，大会検査を 行う際，特別な安心感があります，私ども連盟とし ては，大会にいらして頂くスタッフとしての薬剤師 さんには，検査を担当するというだけではなく，競 技に対して興味を持って頂き，選手ががんばって結 果を出したことへの評価をしてほしい，そんな思い があります，検査室に選手がいらした時，最初にこ ちらから，「優勝おめでとうございます」という挨 拶から始まることで，どれほど雰囲気が和むことで しょう．検査がスムーズに進む第一歩でないかと思 います。

ここで，現在連盟が押し進めている，薬学部学生 登用によるシャペロン業務について記したいと思い ます。シャペロン業務とはご存知の通り，検査対象 選手への通知，対象選手の検査室到着までの行動観 察が主な内容ですが，当初は，自転車競技の経験も ある人を大会開催地の地元連盟や主催連盟を通して 依頼していました．競技に精通しているというメリ

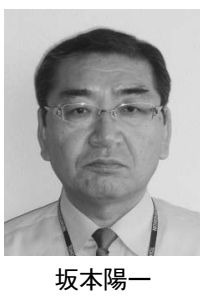

1955 年生. 東北学院大学文学部卒. 東 北学院大学中央図書館勤務. 日本自転 車競技連盟アンチドーピング委員会委 員. 国際自転車競技連合 (UCI) イン ターナショナル・コミッセール．国際 自転車競技連合 DCO（ドーピング・コ ントロールオフィサー)・JADA（日本 アンチドーピング機構）DCO. 自転車 競技のアジア地域におけるアンチドー ピング検査の草分け的存在.アジア大 会を始め多くの国際大会，国内大会で 活躍中. 
ットは多いですが，反面，問題点も浮き彫りになり ました。問題となる具体的な内容とは，皮肉なこと でありますが，シャペロン業務中にしばしば選手監 視の眼が，競技場内で行われている競技の方へいつ てしまう，このようなことがしばしば起きてしまい ました。シャペロン業務の内容があまりよく理解さ れていなかった最初の頃はよかったのですが，その 求められる内容が周りに知れ渡るようになつた昨今 では，シャペロンのこのような行動は検査そのもの への信頼関係を崩すことにもなりかねません.

これに対して薬学部生登用によるメリットを挙げ
てみますと，薬学の授業でアンチドーピングに関す る基礎知識を学び大会にはそれを実践する形で参加 するため，シャペロニング活動も授業の延長上にあ り，取り組む姿勢が真剣そのものです。その結果得 られる効果は非常に高く, 薬学部学生の真摰にシャ ペロニングをする姿は，選手のみならず周りのチー ムスタッフ，ファンから見ても好印象に映るという 評価を頂いております。これは，アンチドーピング 活動がよりよく理解されることにもつながることで あり，連盟としても大いに期待するところでありま す. 